\title{
DEVELOPMENT STRATEGIES IN ARSENAL AS A UPT DISSENLEKAL NAVY DISTRIBUTION LOGISTICAL SUPPLIES CLASS V
}

\author{
Ahmadi, Sutrisno, Arie Handito, I Nengah Putra A \\ Indonesian Naval Technology College, STTAL. \\ Bumimoro-Morokrembangan, Surabaya 60187, Indonesia
}

\begin{abstract}
Planning Information Systems and Information Technology (SI/IT) is part of the Strategic Plan (Renstra) of an institution. Every institution or organization must have a framework for developing information systems and documentation that is adequate and in line with developing systems and technologies. A comprehensive and integrated strategic information system planning is needed by a supply and logistics institution, especially Arsenal with capacity as the Dissenlekal Task Force of the Indonesian Navy Headquarters (Mabesal) in the management of TNI AL Class V logistics. In general this research is a efforts in developing strategic IS/IT planning and identification of their needs at the Arsenal institution as UPT Dissenlekal Mabesal to be more optimal so that it can be integrated and support the strategic planning of logistics supplies within the Navy. The basic concept in this research begins with the preparation of the IS/IT Strategic Plan framework using the Ward and Peppard model approach, then in the evaluation process the translation of the Strategic Plan IS/IT and management of the institution's basic tasks using Balance Scorecard. Some analytical methods such as Value Chain Analysis, SWOT Analysis, PEST Analysis and Five Force Model Analysis are used to analyze the internal and external institutional environment. Next is the McFarlan Analysis Strategic Grid method that is used for application portfolio planning. The results of this research are the recommendations of the relevant IS/IT blue print strategic planning owned by Arsenal UPT Dissenlekal Mabesal and development priorities by referring to the institution's main task plan based on data obtained through the implementation of analytical methods. The information produced will be integrated data for administrative needs and services for related work units. The optimal implementation of information data processing as well as increasing the role of stakeholders in the provision of infrastructure will improve the quality of logistics management services in the fifth grade of the Navy Navy logistics in a comprehensive and integrated manner.
\end{abstract}

Keywords : IS/IT Strategic Planning, Ward and Peppard Model, information systems, information technology.

\section{INTRODUCTION.}

\subsection{Background}

Arsenal is the Technical Implementation Element of the Materiil Weapon and Electronics Service of the Navy (UPT Dissenlekal) which is located directly under the Dissenlekal. Arsenal carries out functions such as preparation and preparation and carrying out activities related to the logistics of class $V$ in the Navy. In carrying out the main tasks, Arsenal are often faced with various types of problems including the lack of a periodic mechanism for distributing Class V (PUT/PUS) supplies due to the absence of IS/IT bridging the needs of operational units and lack of infrastructure planning and management. information technology so that it seems to not follow changes in current technological trends and lack of capacity to accommodate 
the needs of information systems and the provision of information technology so that it is slow in handling equipment dysfunction. With the existence of a number of examples of these cases, the strategic planning of IS/IT is needed by Arsenal institutions as a formulation and contribution in overcoming various problems in the field of management, distribution and provision of provisions of the Indonesian Navy. Information Technology (IT) is the result of human engineering on the process of delivering information from the sender to the recipient so that the transmission of information will be faster, wider in distribution and longer in storage. while KC Laudon was quoted from Sherly

(Semnastik, 2016), explaining that Information Systems (IS) is a relationship between humans, procedures and the use of technology to collect, process, store, disseminate and present information used by one or several business processes in the organization. In preparing a quality IS/IT strategy plan in the Arsenal institution, analysis is needed both internally and externally so that information technology development (IT) policy recommendations can be obtained that can help optimize the implementation of the core institutions. The process of formulating an IS/IT strategy should not be focused on the analysis of certain technologies, but such as the importance of analyzing current problems and changing environmental conditions and awareness of the development of IS/IT are variables that can directly influence Arsenal institutions both internally and externally. In this research, the achievement results in the form of a blue print of the Strategic Plan can be used as a solution to find the gap between the IS/IT that Arsenal currently has compared to the relevant IS/IT and can determine the objectives and development of the next Arsenal institution. Based on the description above, the author takes the title "Arsenal Development Strategy As Dissenlekal UPT in Distributing Logistics Provisions of the Class V Navy".

\subsection{Research Purposes}

The objectives of this research are :

1) Analyzing the IS/IT strategy that has been running at the Arsenal institution then assessing and comparing whether the IS/IT strategy to be implemented will be able to support the performance of Arsenal's main tasks in general.

2) Designing and developing IS/IT strategic planning to be able to improve and support the main tasks of the Arsenal institution in order to achieve the stated vision, mission and objectives.

\subsection{Research Methodology}

The thing that is done by a researcher or writer before conducting research is to always determine the approach that is considered most appropriate to the problems to be solved. Then other considerations are located on the issue of efficiency, namely by considering the limitations of funds, labor, time and capabilities of the researcher. The research methodology used in this research is qualitative methodology. The data collection techniques are as follows:

1) Observation, make direct observations of the object of research in this case the institution of Arsenal as the person in charge of the management and distribution of logistics supplies for the Navy Class V.

2) Interview, do a question and answer with the key person to the Head of Arsenal 
along with the ranks of staff in connection with the analysis of environmental conditions.

3) Document Analysis, analyze documents relating to IS / IT at the Arsenal institution.

4) Literature Study, using references related to IS / IT strategic planning in the form of source books, scientific journals and prior research on IS / IT strategic planning.

\section{3) MATERIAL/METHODOLOGY.}

\subsection{Strategic Planning.}

Strategic planning is a long term plan that is comprehensive and provides a formula for an institution or organization relating to the allocation of resources for achieving goals within a certain period of time.

According to Umar (2002), defining strategy as a process of determining the plans of top leaders who focus on long-term goals of the organization, accompanied by the preparation of a way or effort how to achieve these goals. According to McLeod, as quoted by Nurjaya (2008), states that strategic planning is a participatory, systematic, ongoing process that helps an organization to focus all activities to achieve its mission and ensure that all its staff work to achieve the same goals.

\subsection{Information Systems Strategy.}

Information System Strategy can be defined as a system that helps institutions and organizations improve their long-term performance by directly contributing value added to the optimization chain.

Information system strategy as a use of information technology to support or implement competition strategies from companies (Dede Kurniadi, 2016) and their utilization can increase competitiveness.
Based on the opinion above, the information system strategy is a statement about policy information that contains the goals and objectives and actions taken within a certain period of time. Information strategy is a tool that is applied in the framework of an institutional information policy that is supported by appropriate systems and technologies for the purposes of maintaining, managing and implementing information resources.

\subsection{Strategic Information Systems Information Technology (IS/IT) Modeling.}

The strategic model of IS/IT that will be developed through this research is expected to produce a plan that can make a real contribution to the institution of Arsenal. This model consists of several input as follows :

1) The internal environment of the Arsenal institution: The strategy of maintaining and storing and distributing the logistics supplies of the Indonesian Navy class V.

2) The external environment of the Arsenal Institution: The mechanism and efficiency of demand for class $V$ supplies.

3) Internal IS/IT environment: The IS/IT perspective according to current conditions, technology scope and infrastructure.

4) External IS/IT environment: Technology trends used by user unit elements.

Output produced, namely :

1) Strategy for implementing the main tasks: How will each part or staff develop IS/IT in achieving the objectives of its main tasks.

2) IS/IT management strategy: Implementation of a strategy that is applied in a comprehensive manner will guarantee the 
consistency of the implementation of the next main task.

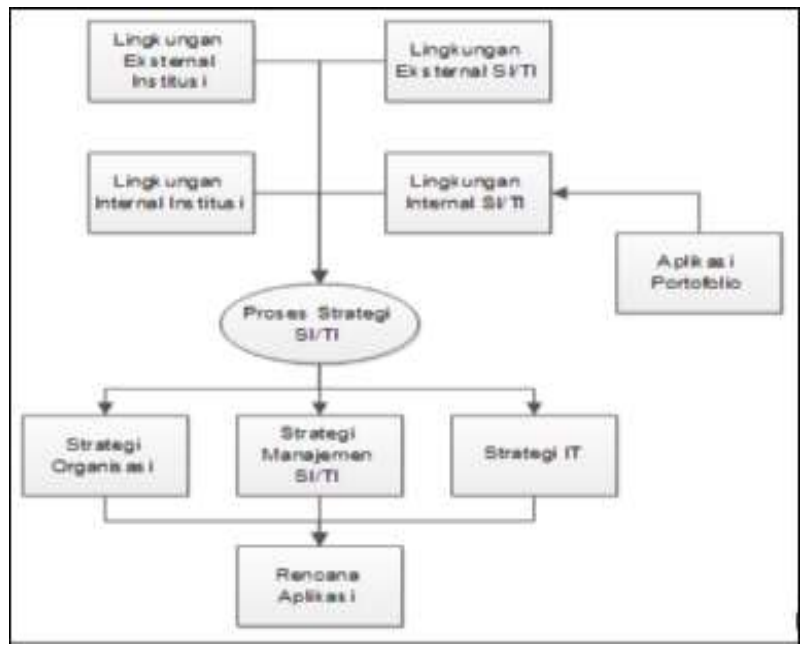

Fig. 1 Strategic Model of the Arsenal Institution Information System Modified from

Ward And Peppard Model

\subsection{SI Planning Formulation and Process} Framework.

In general, the framework for the formulation of IS/IT strategies and planning processes (Ward, 2002) includes the following stages :

1) Initializing the strategy process: is the initial stage where the objectives, objectives and scope have been confirmed first. Personnel involved to participate have been identified. Work plans, scheduling and responsibilities of each part have been verified and defined.

2) Understanding the current conditions by analyzing strategies faced with possible factors such as strengths, weaknesses, opportunities and threats, and information needed.

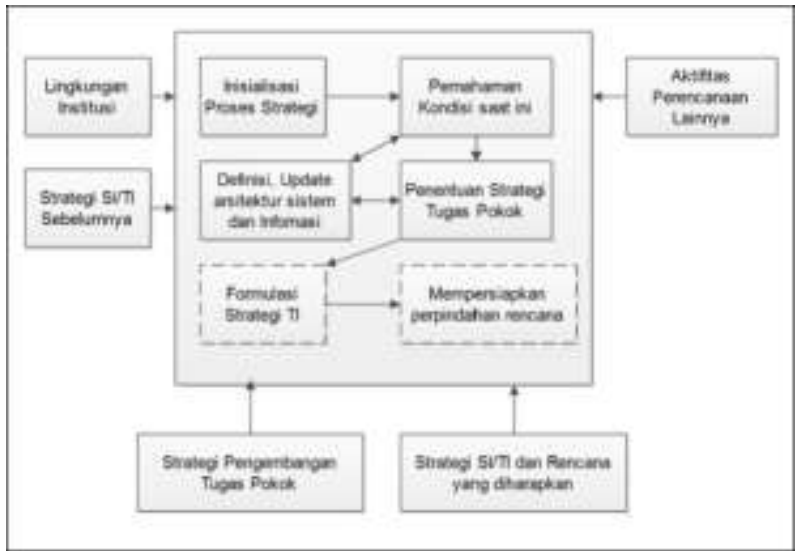

Fig. 2 Modified Formulation Framework and SI Planning Process from Ward And Peppard Model

\subsection{Five Forces Model Analysis.}

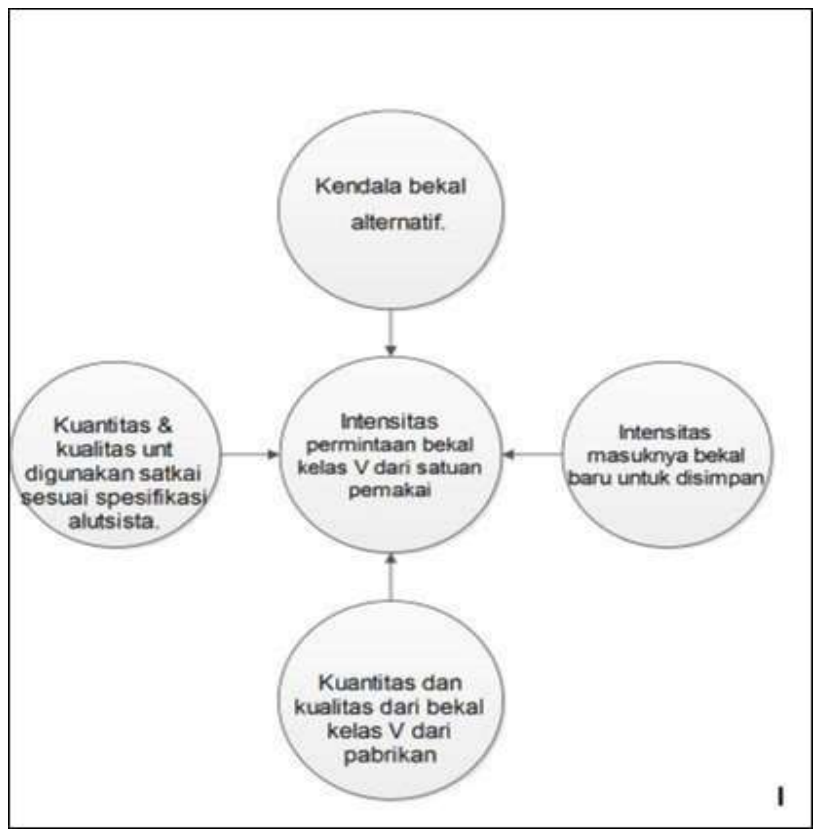

Fig. 3 Arsenal Institution Five Strength Model Plan Adapted to the Five Forces Model

According to (Porter, 1998) in a five forces model, we must anticipate 5 external forces that can be obstacles, including :

1) The intensity of demand for class $V$ supplies from the user unit.

2) The intensity of the entry of new provisions to be stored.

3) The quantity and quality of class $\mathrm{V}$ supplies from the manufacturer. 
4) Quantity and quality to be used by the user unit in accordance with the defense equipment specifications.

5) Alternative provision constraints.

\subsection{Value Chain Analysis.}

With the activities of the main tasks possessed by Arsenal as UPT Dissenlekal Mabesal in an effort to distribute logistical supplies for the Navy class V, the Value Chain or value chain method can be applied in an effort to help identify problems in the distribution of supplies. Value chain is a collection of activities or activities within an organization or institution that are carried out to design, send and support supplies or products. The concept of value chain was first introduced and popularized through the book written by Michael E. Porter in 1985. In the general value chain, supporting activities consist of institutional infrastructure, human resource management, technology development and business acquisition. Whereas the main activities consist of incoming logistics, operations, outbound logistics and services.

Main Activities consist of :

1) Logistic Entry, is an activity or activity that is connected with receipt and storage. Examples of activities such as warehousing, inventory control, loan schedules and returns.

2) Operations are activities associated with input and output, such as equipment maintenance and material testing.

3) Outbound Logistics is an activity related to the collection, storage and distribution of products to user units, such as stock warehousing, material handling, shipping operations.

4) Service, is an activity associated with the provision of services to increase the value of stock. such as installation, repair, training and provision of supplies.

Supporting Activities consist of :

1) Procurement, an activity that refers to the purchasing function such as, stock of other types of provisions that can be used as assets such as machinery, laboratory equipment, offices and buildings.

2) Technology Development is an activity consisting of various groups in an effort to improve products and processes.

3) Human Resource Management is a human resource management activity that includes recruitment, training, $\mathrm{HR}$ development activities.

4) Firm Infrastructure is an organizational infrastructure activity consisting of general management, planning and finance.

\subsection{SWOT Analysis.}

SWOT Analysis (Strengths,

Weaknesses, Opportunities, Threats) are used to assess the strengths and weaknesses of the resources owned by the organization and external opportunities and challenges to be faced. Internal analysis using the SWOT method is by looking at the strengths and weaknesses within the organization. While opportunities and threats are factors that come from outside the organization (Hutabarat and Huseini, 2006). Some conclusions from SWOT Analysis such as :

1) What is the best way to use institutional resources by considering the internal and external situation of the institution, namely to overcome internal weak (Nurjaya, Indonesia Bandung. 2008) nesses that are owned and to defend them from external threats. (Hutabarat, 2006) 
2) How to build an institutional resource base in the future.

With the SWOT analysis, it can be seen whether the institution's position has a sound fundamental or not. This analysis has the principle that the strategy must fit between the capabilities of the company's resources with the external environment situation (Assen, 2009.) So that the accuracy of understanding the capabilities of institutional resources and their shortcomings and external threats is very important for making relevant strategies.

\subsection{PEST Analysis.}

PEST analysis is related to the influence of the environment on an institution. PEST is a useful method or tool for summarizing the external environment in logistics service operations. PEST must be followed up with consideration of how logistics services are faced with the influence of 4 aspects, namely :

1) Politic, covering government policies, legal issues, formal and informal rules of the environment in which an institution carries out activities.

2) Economic, covering the state of the economy at present and in the future that can affect the progress and strategy of an institution.

3) Social, including concentration on the assessment of the attitudes of institutional personnel that influence the strategy.

4) Technology, includes planning strategies that are effective for the environment to look for technological changes that can affect operations because technological changes can provide great opportunities to improve results, objectives or threaten the position of the institution.

\subsection{Grid McFarlan Analysis.}

The McFarlan Grid method aims to analyze an application or information system in an organization's operations based on current conditions, planned conditions and applications that are considered to have potential in supporting operations (Purwanto, 2010) So that it can facilitate management in making decisions in determining the position of IS/IT institutions in accordance with the capabilities and vision and operational mission of the institution in the future. Application Analysis Portfolios are used to map current applications and meet future application needs to support the performance of an organization. This application mapping consists of four quadrants (strategic, high potential, key operation, and support) according to the assessment category of an application that has an impact on the institution. From the results of the mapping, an illustration of the contribution of SI to the institution was obtained. These results can be an input for SI strategic planning activities and the possibility of future development (Rahayu, Bandung, 2009)

\subsection{Balance Scorecard IT.}

Based on Nurjaya's quote (2008) argues that in 1997, Van Grembergen and Van Bruggen adopted the Balanced Scorecard (BSC) to be used in the

Organization's Information Technology Department. In their view because the Information Technology Department is an internal service provider, the perspective used must be changed and adjusted.

\subsection{Object Of Research.}

The position of Arsenal is as a Technical Implementation Element of the 
Materiil Weapon and Electronics Navy (Dissenlekal UPT) Office under the Dissenlekal.

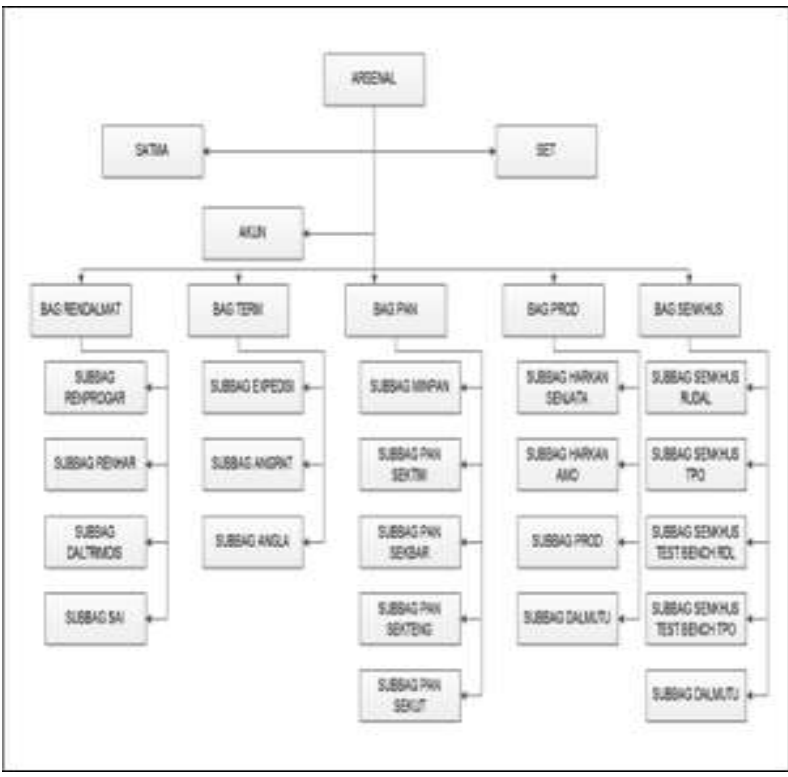

Fig. 4 Arsenal Institution Organizational Structure

Arsenal has the main task of carrying out limited guidance on all the material of special weapons, general weapons and ammunition within its scope of responsibility in order to provide material support for special weapons, general weapons and ammonition to other Indonesian Armed Forces elements.

The IS/IT strategic planning method based on the (Ward, 2003) Model has two stages, namely input and output. The input stage consists of an analysis of the institution's internal environment, analysis of the institution's external environment, analysis of the internal environment of IS/IT and analysis of the external environment of IS/IT. For the output stage, namely the SI strategy, the IS/IT strategy and the IS/IT management strategy. The stages can be seen in the following picture.

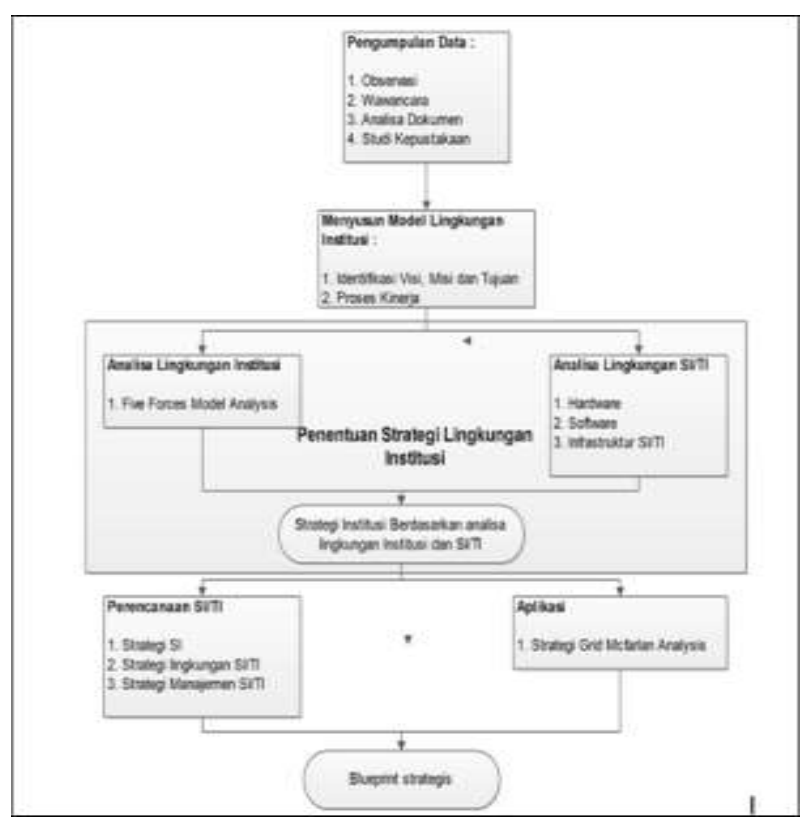

Fig. 5 Research Methods

\subsection{Data Collection.}

Data collection techniques in this study are as follows :

1) Observation, carried out research for direct observation of the object of research in this case the Arsenal institution which is responsible for the management and distribution of logistical supplies for the Navy class V.

2) Interview, conduct question and answer with the key person to the Head of Arsenal along with the ranks of staff related to environmental conditions and their potential for development.

3) Document Analysis, analyze documents related to IS/IT at the Arsenal institution at this time along with supporting data.

4) Library Studies, uses references related to IS/IT strategic planning. 


\subsection{Arranging the Arsenal Institutional} Environment Model.

Identifying the vision, mission and objectives to be achieved The Arsenal Institution then compiles the process of implementing the main tasks related and describing in the main task model.

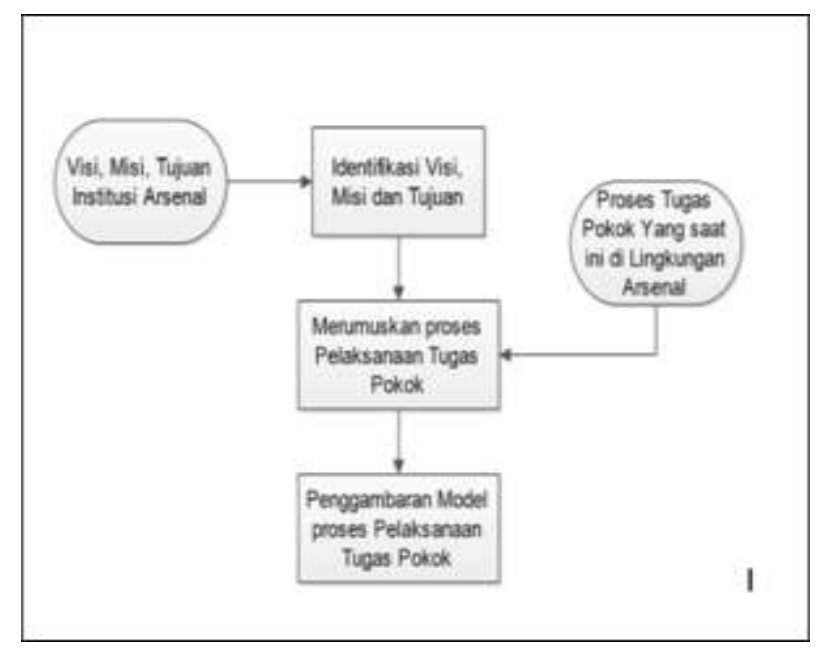

Fig. 6 Model preparation framework

\subsection{Determination of Strategy for Arsenal Institution Performance.}

Analyze the main tasks in the internal and external environment and conduct an environmental analysis of the IS/IT that is currently running at the Arsenal institution. Internal and external environment analysis using the Value Chain, SWOT, PEST, Grid Mcfarland and Five Forces Model methods. Then proceed with conducting environmental analysis of IS/IT which includes hardware, software and IS/IT infrastructure. The results of this stage are the determination of the main task strategy based on institutional environmental analysis and IS/IT environmental analysis.
Internal and External Environmental Analysis:

1). Analysis of the internal environment using the Value Chain method. The output produced is the process of carrying out the performance of the main tasks of the Arsenal institution that have been grouped based on primary activities and support activities.

2). Analysis of the external environment using the PEST method to identify external factors that influence the process of implementing the performance of the main tasks of the institution of Arsenal. The output produced is a grouping of external factors that influence the performance process based on political, economic, social and technology aspects.

3). Analysis of the internal environment using the Five Forces Model method to identify external forces that have the potential to pose a threat to the process of Arsenal's institutional performance. The output produced is the aspect of the intensity of the provision of supplies, the distribution of supplies in and out and the substitute stock that will fill.

4). Analysis of internal and external environments using the SWOT method.

Defining strengths, weaknesses, opportunities and threats from Arsenal institutions. Outputs produced are strengths, weaknesses, opportunities and threats as well as strong-opportunity (SO), weaknessopportunity (WO), strong-threat (ST) and weakness-threat strategies (WT).

\section{IS/IT Environmental Analysis:}

1). Hardware, defines the hardware specifications that have been applied at the Arsenal institution, then plans to implement the latest hardware technology that is 
suitable to be applied at the Arsenal

institution.

2). Software, defining software specifications that have been implemented at Arsenal institutions, then compiling a plan for implementing software that is needed and can be applied at the Arsenal institution.

\subsection{IS/IT Planning.}

Designing Arsenal's IS/IT strategic planning using the following framework :

1). Developing an IS/IT Strategy, covering policies and strategies for the management of IS/IT and its resources.

2). Arranging Strategies for IS/IT main tasks, including how each staff or part will utilize IS/IT to achieve the goals, portfolio and description of information architecture.

\subsection{Evaluation of The Description of}

The IS/IT Strategy And Bussiness

Strategy.

Evaluate the translation of IS/IT and external internal environment strategies using the Balanced Scorecard Tools.

Here are 4 perspectives in evaluating the description of IS/IT strategies and external internal strategies :

1). Organizational Contribution

Perspective.

2). User Orientation Perspective.

3). Operational Excellence Perspective.

4). Future Orientation Perspective.

\section{RESULT AND DISCUSSION.}

\subsection{Compile Arsenal's External Internal Environment Model.}

1) Identification of Vision, Mission and Objectives.

The following is the model of the vision, mission and objectives of the Arsenal institution :

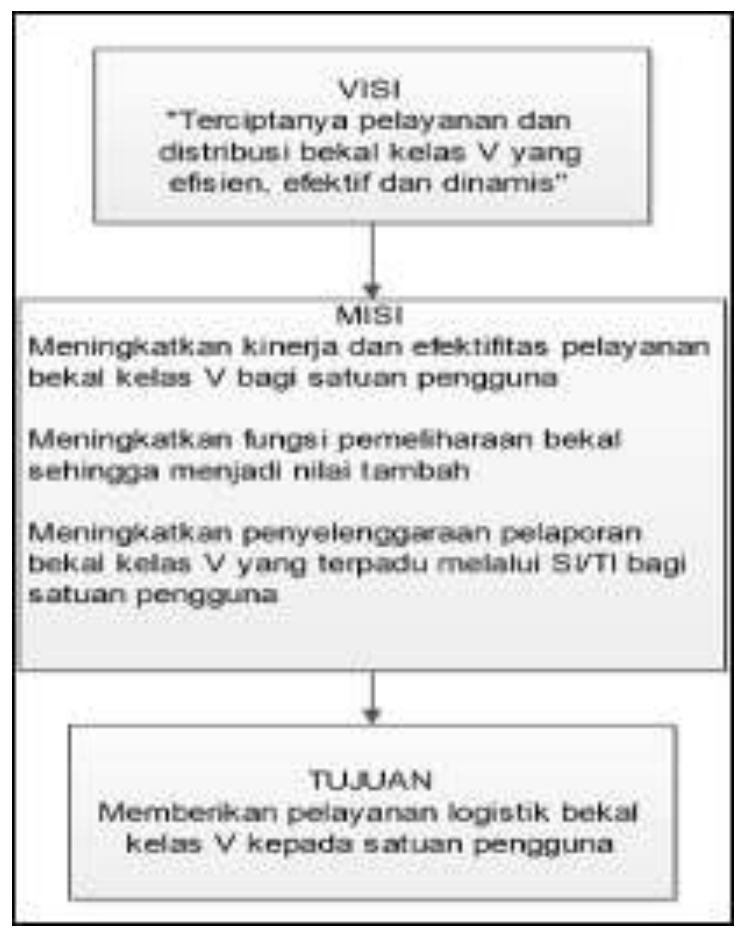

Fig. 7 Arsenal's Vision, Mission and Objectives Plan

Based on the vision, mission, objectives determined by the institution of Arsenal, the authors identified that the Arsenal institution has a commitment to develop IS/IT to be able to assist the operations of the Arsenal institution so that it can improve efficiency and effectiveness in the provision of logistics services for Navy Class V. 
2) Process of Logistics Activity Activities at Arsenal.

At the Arsenal institution there are several logistics activities that are often carried out including the following:

a) Request Process To Receive Ammunition, Light Weapons and Explosives.

b) Request Process for Submitting Ammunition, Light Arms and Explosives

c) The process of storing and maintaining to hand over ammunition, light weapons and explosives.

d) The process of processing and destroying ammunition, light weapons and explosives.

\subsection{Determination of Internal Environmental Logistics Activity Strategies.}

1) Internal Business Analysis by using Value Chain analysis

This analysis is carried out to map all activities in carrying out the main tasks that occur at Arsenal which are classified into two activities, namely the main activities and supporting activities.

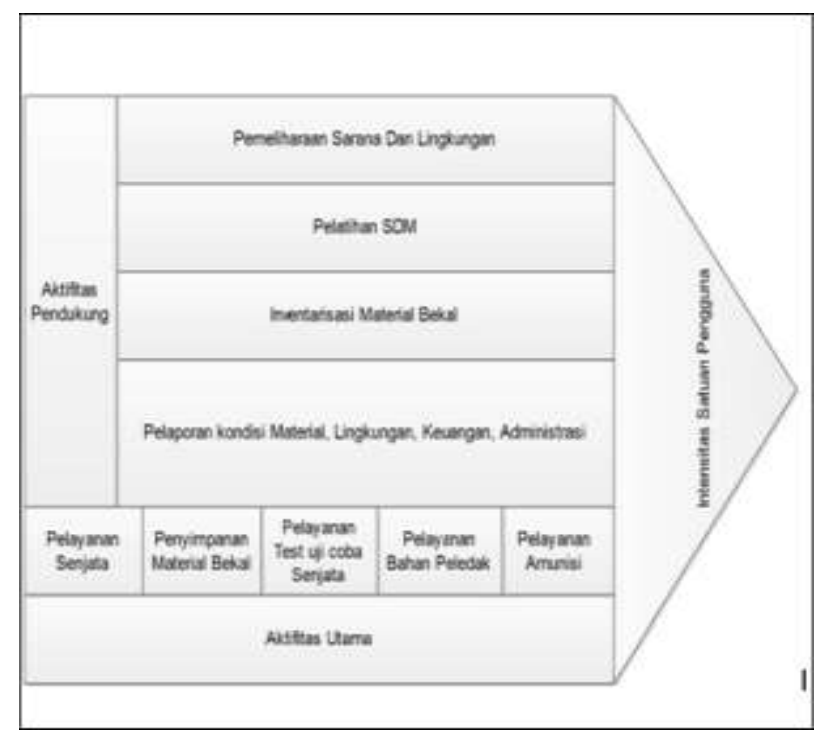

Fig. 8 Arsenal's Value Chain
Arsenal's main activities are as follows:
a) Weapon Service
b) Materal Storage Stock
c) Weapon Test Test Service
d) Explosive Services

e) Ammunition Services

Arsenal's supporting activities are as follows:

a) HR Training

b) Maintenance of Facilities and Environment

c) Inventory of Stocking Materials

d) Reporting on Material, Environmental and Financial Conditions

e) Inventory data collection.

2) Eksternal Environmental analysis with PEST analysis

The following are some external factors that influence the performance process. Arsenal's main tasks are based on PEST analysis :

a) Politics

i. Decree of the TNI Commander Number Kep/137/II/2017 dated February 21, 2017 concerning the Guidelines for Implementing the

Preparation and Issuance of Guidelines in the Indonesian National Army Environment.

ii. Regulation of the Navy Chief of Staff Number/69/XI/2010 dated November 2, 2010 concerning the Indonesian Navy (PUM-7) Logistics Guidance Manual.

iii. Regulation of the Navy Chief of Staff Number Perkasal/103/XII/2010 dated December 31, 2010 concerning the Indonesian Military Navy Guidance for Guidance for the Guidance for the Development of the Navy (PUM-7.02). 
b) Economy

From an economic standpoint, this will affect the conditions of the Indonesian Navy defense equipment which have an impact on the maintenance and purchase of defense equipment to support the MEF.

c) Social

The higher level of knowledge will affect the performance and increaseof effective logistics services.

d) Technology

The current technology has led to increased ease of access to class $V$ stock distribution. This will have an impact on increasing the quality of Navy training activities.

3) External Environmental Analysis using the Five Forces Model analysis

The following are some external factors that influence the process of the performance of Arsenal's main tasks based on the Five Forces analysis model:

a) The intensity of demand for class $V$ supplies from the user unit.

The increasing demand for class $\mathrm{V}$ supplies, it will have an impact on the minimum stock of supplies in the warehouse. So that the condition that is not avoided is that the user unit needs to do the operation training but the stock material requested is not available.

b) The intensity of the entry of new provisions to be stored.

Provisions in the new condition will be accommodated first in the storage warehouse. What should be avoided is that the old stock has not been absorbed maximally by the user unit so that the condition of the special warehouse will experience excess capacity.

c) Quantity and quality of class V supplies from the manufacturer.

The quality of good provisions will maintain the condition of the stock provisions. So the quality of good lunch will have a relatively long life cycle.

d) Quantity and quality for use by user units in accordance with defense equipment specifications.

Material conditions and the amount of material requested will be adjusted to the user unit specifications. If the quality of the stock material decreases, it will affect the defense equipment condition.

e) Alternative provision constraints.

If the stock of stock material is used up, the solution is to wait until the specified time. Some user units or users overcome this condition with the loan process.

4) Internal Environment Analysis using SWOT analysis

Analysis uses the SWOT matrix (Strength, Weaknesses, Opportunities, Threats) as follows :

a). Strategy SO (Strength - Opportunities) The SO strategy is an internal environment strategy in the SWOT analysis that is using power by exploiting opportunities. Following is the SO strategy table based on SWOT identification. 
Table 1. SO Strategy (Strength - Opportunities)

\begin{tabular}{|c|c|c|c|c|}
\hline No & So strategy & Description & CSF & Proposed SI IT \\
\hline T & 2 & 3 & 4 & 5 \\
\hline 7 & $\begin{array}{l}\text { The development of } \\
\text { HR's knowiledge } \\
\text { disseminationsystem } \\
\text { has increased }\end{array}$ & $\begin{array}{l}\text { Irainang personnelto } \\
\text { improve expertise }\end{array}$ & $\begin{array}{l}\text { Arsenal must } \\
\text { provide support and } \\
\text { facilities to improve } \\
\text { the performance of } \\
\text { key tasks }\end{array}$ & $\begin{array}{l}\text { Hre application for } \\
\text { Arsenal personnel }\end{array}$ \\
\hline 2 & $\begin{array}{l}\text { Development of logrstics } \\
\text { service facilities for the } \\
\text { ease of the distribution } \\
\text { process of class } \mathrm{V} \\
\text { supplies }\end{array}$ & $\begin{array}{l}\text { Support personnel by } \\
\text { providing equipment } \\
\text { needled for the } \\
\text { execution of tasks }\end{array}$ & $\begin{array}{l}\text { Grve authority to } \\
\text { personnelto carny } \\
\text { out the } \\
\text { performance } \\
\text { process with } \\
\text { discipline }\end{array}$ & $\begin{array}{l}\text { Applicatson Lecision } \\
\text { Support System } \\
\text { Arsenal performance }\end{array}$ \\
\hline 3 & $\begin{array}{l}\text { System development to } \\
\text { assess the performance } \\
\text { of each personnel so } \\
\text { that it can be monitored } \\
\text { by the supenvisor }\end{array}$ & $\begin{array}{l}\text { The abolity to access } \\
\text { personnel data }\end{array}$ & $\begin{array}{l}\text { The personnel } \\
\text { Division must } \\
\text { provide data for } \\
\text { each personnel } \\
\text { required by the } \\
\text { Head of the } \\
\text { Division, such as } \\
\text { attendance data, } \\
\text { performance data }\end{array}$ & $\begin{array}{l}\text { Application Decision: } \\
\text { Support System } \\
\text { Arsenal performanoe }\end{array}$ \\
\hline 4 & $\begin{array}{l}\text { System development } \\
\text { that can provide } \\
\text { monitoring of the } \\
\text { conditions of stock } \\
\text { material in the current } \\
\text { user unit }\end{array}$ & $\begin{array}{l}\text { Improve S1 on the } \\
\text { Arsenal website which } \\
\text { can provide } \\
\text { information on stock } \\
\text { conditions saat ini }\end{array}$ & $\begin{array}{l}\text { Development of } \\
\text { functions from the } \\
\text { Arsenal webs ite }\end{array}$ & $\begin{array}{l}\text { Arsenal Expert } \\
\text { System Logistics } \\
\text { Website Application }\end{array}$ \\
\hline 5 & $\begin{array}{l}\text { Development of } \\
\text { centrafized data } \\
\text { organizing facilities so } \\
\text { that they can be used in } \\
\text { every division that } \\
\text { needs them. }\end{array}$ & $\begin{array}{l}\text { Data for each drvisiorn } \\
\text { must be integrated }\end{array}$ & $\begin{array}{l}\text { Bund one main } \\
\text { database senver in } \\
\text { Arsenal }\end{array}$ & $\begin{array}{l}\text { Distributed Darabase } \\
\text { Application }\end{array}$ \\
\hline 0 & $\begin{array}{l}\text { Development offaclifes } \\
\text { that can store every } \\
\text { document or book that } \\
\text { can be accessed }\end{array}$ & $\begin{array}{l}\text { Provide convenience } \\
\text { for personnel to be } \\
\text { able to upload and } \\
\text { downlabd documents. }\end{array}$ & $\begin{array}{l}\text { Bund one main } \\
\text { database server in } \\
\text { Arsenal }\end{array}$ & $\begin{array}{l}\text { Clinac Document } \\
\text { System Application }\end{array}$ \\
\hline
\end{tabular}

b). WO (Weakness - Opportunities) Strategy

The WO strategy is an internal environment strategy in the SWOT analysis that is using power by exploiting opportunities. Following is the WO strategy table based on SWOT identification.

Table 2. WO Strategy (Weakness - Opportunities)

\begin{tabular}{|c|c|c|c|c|}
\hline No & Strategi WO & Deskripsi & $\mathrm{CSF}$ & $\begin{array}{l}\text { SI/TI yang } \\
\text { diusulkan }\end{array}$ \\
\hline 1 & $\begin{array}{l}\text { Utilizing the budget to } \\
\text { build facilities to improve } \\
\text { the performance of } \\
\text { basic tasks }\end{array}$ & $\begin{array}{l}\text { Utilization of the } \\
\text { Navy's central budget } \\
\text { to build facilities to } \\
\text { increase the } \\
\text { distribution of class V } \\
\text { supplies to user units }\end{array}$ & $\begin{array}{l}\text { Utilization of the } \\
\text { Navy's central } \\
\text { budget to build } \\
\text { facilities to increase } \\
\text { the distribution of } \\
\text { class V supplies to } \\
\text { user units }\end{array}$ & Financial Application \\
\hline 2 & $\begin{array}{l}\text { Develop a strategic } \\
\text { system for effective } \\
\text { distribution of class } V \\
\text { supplies to the user unit }\end{array}$ & $\begin{array}{l}\text { ntegrated information } \\
\text { delivery for information } \\
\text { on class } V \text { supplies to } \\
\text { user units }\end{array}$ & $\begin{array}{l}\text { Arsenal must make } \\
\text { an integrated } \\
\text { logistics information } \\
\text { system for the user } \\
\text { unit }\end{array}$ & $\begin{array}{l}\text { Integrated logistics } \\
\text { information system } \\
\text { application }\end{array}$ \\
\hline
\end{tabular}


5) Analysis of Internal IS/IT Environment Internal IS/IT analysis is an environmental analysis that highlights the aspects of IS/IT held by current Arsenal institutions. In general Arsenal institutions already have a system that is still conceptual and not yet an integrated system. While for the implementation of technology at the Arsenal institution, it is still supporting operational activities.

6) External IS/IT Environmental Analysis

External IS/IT analysis is carried out to observe the current condition of the development of IS/IT.

a) IS/IT Production

Party or manufacturer Production or manufacturer of the Arsenal institution is a class $\mathrm{V}$ stock maker. The producers have implemented IS/IT, namely by using distribution applications in logistics activities.

b) Current IS/IT developments

The development of IS/IT is very rapid, both the application of information technology and the application of applications in a business. Distributed information system is the most appropriate thing to be applied in every organization because it will support thedistribution mechanism of provisions carried out between institutions so that the operations will be more effective and efficient.

\section{7) IS/IT Planning \\ After carrying out the stages of the} Arsenal and IS/IT environment analysis based on the Ward and Peppard Model approach, the author formulated several proposals regarding IS/IT strategic planning, namely the future application requirements for Arsenal.

\subsection{Application Requirements}

Preparation of application requirements is based on the results of an external internal environment analysis and the IS/IT environment at Arsenal. Following are the proposed application requirements that will later be applied at Arsenal :

1) Integrated information system application :

Application This integrated information system is needed for the management of PUS, PUT, and distribution of class V supplies.

2) Financial Application :

This financial application is needed for Arsenal's financial management.

3) Warehousing Application :

This pharmacy application is needed for managing data on availability of logistic at Arsenal.

4) Inventory Application :

This inventory application is needed for data management of facilities and infrastructure of Arsenal.

5) HR Application :

HR application is needed for data processing assessment of Arsenal personnel starting from attendance, achievements, work processes and training.

6) Performance Decission Support System Application :

This performance DSS application is needed for decision support systems regarding the performance of all staff and parts that will later give a picture for the heads of divisions or other superiors to carry out or issue policies.

7) Expert Monitoring System Application :

The Expert Monitoring System application is needed to provide information 
about the distribution of class $\mathrm{V}$ logistics supplies to the user unit.

8) Application of Supply Chain Management :

Supply Chain Management applications are needed to build a distributed information system regarding the management of stock availability, facilities and other support.

9) Document System Application :

The document system application is needed to build a main database server that manages the entire document flow at Arsenal 10) Executive Information System Application

The application of executive information systems is needed by top echelon officials in accessing and checking Arsenal's facilities, infrastructure, finance, operations and policies

11) Information System Application provision for Class V :

Information System Application provision for Class $\mathrm{V}$ is needed to provide information about specifications and the mechanism for distributing provisions to user units.

12) Distributed Database Application :

Distributed database applications are needed to integrate IS Arsenal and provide applications in each division at Arsenal.

13) Clinic Website Application :

Clinical website applications are needed for information facilities in general.

\section{CONCLUSIONS.}

Based on the results of the research conducted on information system strategic planning at Arsenal, conclusions can be drawn:

1) Arsenal is the Technical Implementation Element of the Materiil Weapons and Electronics
Service of the Navy (UPT Dissenlekal) which is located directly under the Dissenlekal. Arsenal carries out functions such as preparation and preparation and carrying out activities related to the logistics of class $V$ in the Navy. In an effort to improve the performance of basic tasks to be more effective, efficient and optimal is to use information technology as a means of daily activities.

2) The results of the research are an information system strategic planning framework that can be used as an Arsenal guideline in carrying out class $\mathrm{V}$ logistics distribution activities. Proposed IS/IT strategic planning framework for Arsenal institutions in order to find out important factors that needed in developing an information system that is in line with the policies of the Navy leadership. The information system strategic planning approach carried out in this study is based on the Ward and Peppard Model. Where is environmental analysis using Value Chain Analysis, PEST Analysis, Five Force Model Analysis and SWOT Analysis.

The suggestions that the author can give from the results of this study are as follows:

1). The author advises supervisors and Arsenal to make this research a guideline for the development of IS/IT that is in line with the policies of the Navy leadership. The results of this study are also suggested to be used as guidelines in designing information system architecture at Arsenal.

2). For further research on information system strategic planning by using the Ward and Peppard Model to assess the stages of the position of evaluating the information system strategic planning using the Balance Scorecard IT. Where in the research that the author did only at the stage of the evaluation of the laboration of information systems strategic planning was carried out after the stages of IS/IT planning. 


\section{ACKNOWLEDGEMENTS.}

This research has been Supported by Indonesia Naval Technology College (STTAL).

\section{BIBLIOGRAPHY}

Assen, M. (2009.) Key Management Models the 60 models every manager needs to know, $2^{\text {nd }}$ edition, Prentice Hall.

Dede Kurniadi, A.M. ( 2016) 'Implementasi Pengembangan Student Information Terminal (SIT) Untuk Pelayanan Akademik Mahasiswa', Jurnal Algoritma.

Hutabarat, J..H.M. (2006) Operasionalisasi Strategi , Elex Media Komputindo.

Nurjaya, W. (Indonesia Bandung. 2008) ' Model Strategic Planning for Information System
Menggunakan Balanced Scorecard pada Universitas Komputer'.

Porter, M.E. (1998) 'Competitive Advantage Creating and Sustaining Superior', no. New York Free Press.

Purwanto, E. (2010) Strategic Grid McFarlan, Jakarta.

Rahayu, B. (Bandung, 2009) 'Perencanaan Strategis Sistem Informasi (Studi Kasus: PT. AAS)'.

Ward, J..P.J.S.P.f.S. (2002) John Wiley.

Ward, J..a.P.J. (2003) Strategic Planning for Information Systems, $3^{\text {rd }}$ edition, USA: John Wiley \& Sons Ltd. 